\title{
AN OVERSUPPLY OF LAW GRADUATES? PUTTING THE STATISTICS IN CONTEXT
}

\author{
CHRISTINE PARKER*
}

\section{INTRODUCTION}

In the last 12 months there have been a spate of stories in the press warning us of an impending "glut" of lawyers. ${ }^{1}$ The most frequently quoted "fact" is that there are as many law students as there are lawyers. Professor Bob Williams of Monash University has warned that the growing number of law students is a "potential catastrophe", 2 and the Queensland Attorney-General has predicted that "we will end up in the same situation as California, where large numbers of lawyers are wandering around ... looking to create work" by "ambulance chasing” or touting. ${ }^{3}$

But further research into statistical trends for Australian lawyers and students indicates that the real story is more complex and less alarming than the headlines suggest. ${ }^{4}$ First, careful collection of statistics shows that it is simply not true that there are almost as many law students as lawyers in Australia. Secondly, the argument that there are too many law students is fundamentally flawed because it assumes that all law students become lawyers, without sufficiently defining the term "lawyers". It also fails to take account of graduation rates, attrition from the profession and the number of graduates who do not remain in the law. Finally, reports of the student "glut" have taken an ahistorical approach to the statistics and failed to examine the past ratios of students to lawyers.

The purpose of this paper is to set out the statistics as accurately as possible for analysis and planning. Accurate statistics on law students and where they go after graduation, as well as the 
composition of the legal industry, are necessary in order to plan for legal education and to make judgments on the future prospects of law graduates. ${ }^{5}$

\section{"LAWYERS"}

Predictions of lawyer gluts seem to assume that almost all law graduates become "lawyers". Law graduates, however, take a variety of different types of jobs. The "lawyer" statistics that are used to support claims of excessive numbers of students are frequently unclear about which of these jobs are included.

In fact the term "lawyers" is notoriously difficult to define. ${ }^{6}$ For present purposes, it is most useful to define "lawyers" as people recognised as legal practitioners by the professional associations. ${ }^{7}$ The main advantage of such a definition is that statistics collected in the same way in different states and over time by professional associations can be used. ${ }^{8}$ It is also likely to fit both public and professional perceptions of who lawyers are. It covers all solicitors and barristers in traditional private practice. However, membership of such associations will normally depend only on possession of a current practising certificate; there will be some members who have a certificate, but do not actually practise. ${ }^{9}$ Most government legal officers will not be included as they do not normally need a practising certificate. ${ }^{10}$

The professional association with the most comprehensive membership in Australia is the Law Council of Australia, an umbrella organisation for all the State and Territory professional associations. ${ }^{11}$ Law Council of Australia membership figures were available for 1975, 1982 and 1986-1992. ${ }^{12}$ For 1947,1961,1966,1971 and 1981 census figures for lawyers are available. ${ }^{13}$ The census figures are calculated on a similar basis to Law Council of Australia membership since they include people working as barristers and solicitors. But the census statistics also include Judges and magistrates, who are not considered members of the profession by the profession (including the Law Council of Australia), and "legal officers". ${ }^{14}$ Therefore the census figures are slightly more inclusive than the Law Council of Australia data.

It is also necessary to examine how the number of lawyers increases over time. The legal profession will not remain static. One possible indicator of the future rate of growth of the profession 
is its growth in the past.

\section{LAW STUDENTS}

Reliable data on the number of Australian law students is not readily available. All the published series of higher education data put law and legal studies students together. ${ }^{15}$ Many law students complete another degree at the same time as they are studying for their law degree: Some universities categorise combined degree students according to their non-law degree, while others categorise them as law students. Many of the student figures quoted recently are probably inaccurate because they include legal studies students or do not include combined degree students. ${ }^{16}$ Given the fact that people are concerned about a possible glut of lawyers, it seems more pertinent to count all students enrolled in bachelor law degree programs which lead to a qualification for legal practice.

Again the statistics must be placed in their historical perspective. Newspaper reports of the law student "glut" rarely compare the current student to lawyer ratios with previous years. Such an examination may find that a large number of law students have always had to be recruited to fill a smaller demand in the profession, because of the propensity of law graduates to find work outside legal practice.

Since no published series of statistics counted law students in an accurate way, Department of Employment, Education and Training (DEET) computer records of all students in all courses in all Universities were used to collect the student statistics for 19891992. ${ }^{17}$ The Pearce Report collected the same data for the years 1980 to 1984 direct from the Law Schools themselves. ${ }^{18}$ A database collected by Professor Western of the University of Queensland gives a figure for 1965 collected in the same way. The number of law students for 1993 was collected by asking every law school in Australia how many LLB students they had in June 1993. ${ }^{19}$

Since these more accurate statistics do not cover a wide enough period to be useful in any comparison with the statistics for lawyers, 1950, 1960 and 1975 to 1987 figures from Universities Commission/CTEC/DEET publications have also been used in some tables. These statistics will include some legal studies students, but do not include many combined degree students in their first three years of study. Therefore they are probably too 
low. ${ }^{20}$

This paper ignores people who are seeking legal qualifications by means other than enrolling in University degree courses. In New South Wales there were still almost 5000 students registered in Admission Board courses in 1992. ${ }^{21}$ But reliable figures for Admission Board enrollees throughout Australia are not available. The fact that many are not actively pursuing their courses and a large percentage may never finish further confounds consideration of Admission Board enrollees. ${ }^{22}$ Of those who are actively pursuing their courses, many may already have employment in legal practice, for example as five year articled clerks.

\section{RATIO OF LAW STUDENTS TO LAWYERS}

Using the methods and sources described above, statistics for lawyers and law students from 1947 to 1993 can be compiled. Table 1 sets out all the accurate statistics that are available.

According to the Law Council of Australia there were approximately 27900 lawyers in Australia in 1992. There were 15516 LLB students, 56\% of the number of lawyers. In 1993 there were 29165 lawyers and 17108 students, 59\% of the number of lawyers. There are clearly not, therefore, anywhere near as many law students as lawyers. However, there are still a large number of law students and at first glance the ratio of students to lawyers suggests an oversupply.

TABLE 1: Numbers of Australian Law Students and Practitioners 1947-1993

\begin{tabular}{ccc}
\hline Year & LLB Students & Practitioners \\
\hline 1947 & 5711 \\
1950 & $1466+$ \\
1960 & $2257+$ \\
1961 & 6736 \\
1965 & 4076 \\
1966 & 6242
\end{tabular}


1974

1975

1976

1977

1978

1979

1980

1981

1982

1983

1984

1985

1986

1987

1988

1989

1990

1991

1992

1993
7 518+

7 917+

12580

8 249+

12909

8 315+

8 249+

$8225+$

11000

11467

15524

11654

16400

11535

16100

11254

17000

17100

17500

18700

22400

11297

25000

12830

25800

13370

27000

15516

27900

17108
29165

But although the 1993 ratio of 59 students for every 100 lawyers appears quite large, it is not unusual compared with other years. Table 2 shows the ratio of law students to practitioners in the years between 1965 and 1993 for which an accurate figure for both is available. Figure 1 puts that information in graph form to make the trend easier to see. 
FIGURE 1: Lawyers and Students 1965-1993

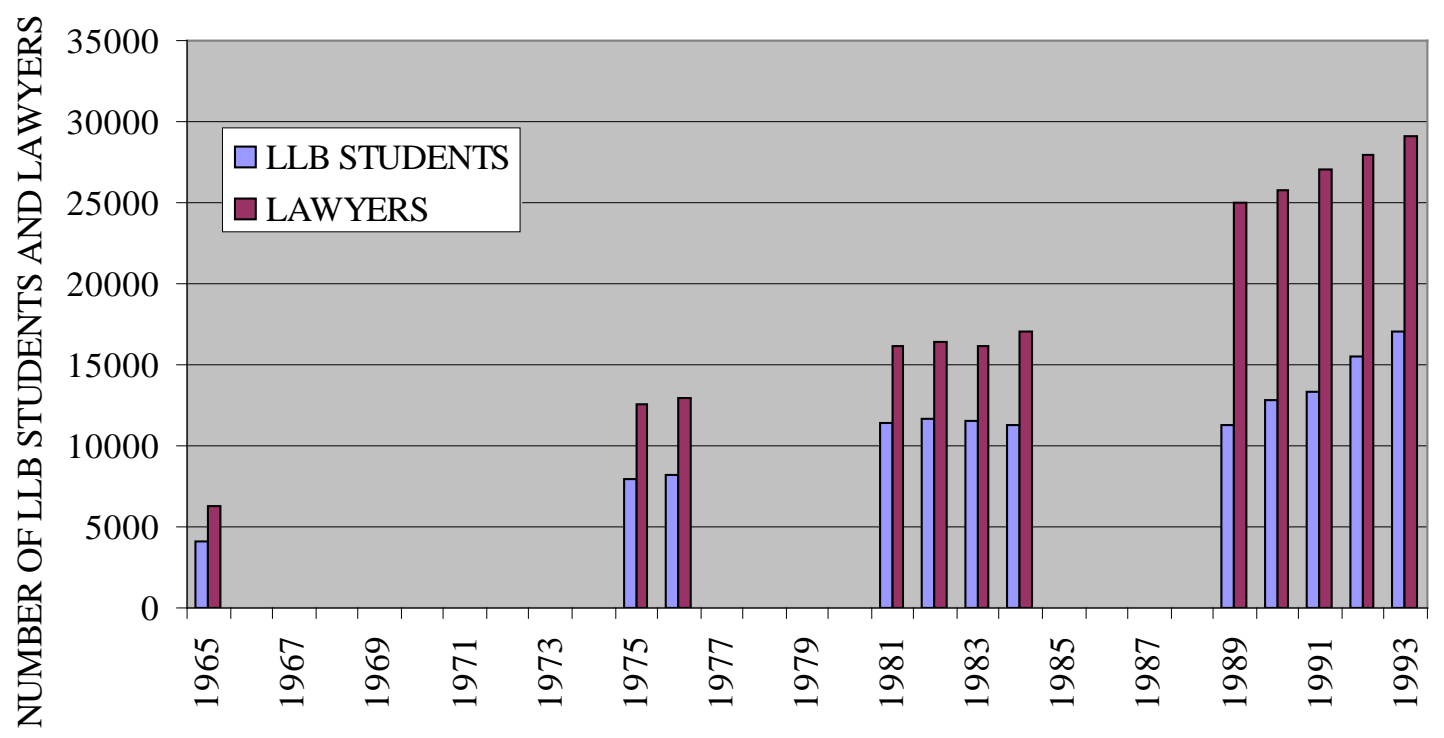


TABLE 2: LLB Students, Lawyers and Ratio 1965-1993

\begin{tabular}{cccc}
\hline Year & LLB Students & Lawyers & $\begin{array}{c}\text { Students as } \\
\text { Percentage of } \\
\text { Lawyers }\end{array}$ \\
\hline 1965 & 4076 & 6242 & $66 \%$ \\
1975 & 7917 & 12580 & $63 \%$ \\
1976 & 8249 & 12909 & $63 \%$ \\
1981 & 11467 & 15524 & $71 \%$ \\
1982 & 11654 & 16400 & $71 \%$ \\
1983 & 11535 & 16100 & $71 \%$ \\
1984 & 11254 & 17000 & $66 \%$ \\
1989 & 11297 & 25000 & $45 \%$ \\
1990 & 12830 & 25800 & $50 \%$ \\
1991 & 13370 & 27000 & $50 \%$ \\
1992 & 15516 & 27900 & $56 \%$ \\
1993 & 17108 & 29165 & $59 \%$ \\
\hline
\end{tabular}

Thus the ratio of students to practitioners has averaged almost two students for every three practitioners since around 1965. Before that time, many practitioners would have qualified by means of Admission Board courses so there were many more "students" than the figures for University enrollees show. ${ }^{23}$

\section{GRADUATIONS}

Even if there were as many law students as practitioners and every graduate became a lawyer, graduation rates and retirements from the profession would mean that it would take some years for the number of practitioners to double. Some reports give an impression that 1993's students will represent 17108 desperate, employment-seeking graduates in 1994. In fact, most will take four to six years to complete their courses. Some will never complete. For example in 1991, there were 13370 law degree students enrolled, but only 2500 completed their degrees. Table 3 shows the 
number of course completions and total number of students enrolled for 1988 to $1991 .^{24}$

TABLE 3: Numbers of Students and Course Completions

1988-1991

\begin{tabular}{ccc}
\hline Year & Completions & Total Enrolments \\
\hline 1988 & 2171 & $?$ \\
1989 & 2245 & 11297 \\
1990 & 2330 & 12,830 \\
1991 & 2500 & 13370 \\
\hline
\end{tabular}

At this rate, it will take five to six years for all current law enrollees to graduate and seek work. ${ }^{25}$

\section{LAW GRADUATES AND THE LEGAL PROFESSION?}

Yet the argument that there are too many law students is seriously flawed at an even more fundamental level. It has already been emphasised that not all graduates go into private practice. But this is implied by comparisons between the number of students and the number of private practitioners.

The Law Council of Australia figure of 29165 lawyers in 1993 includes private solicitors and barristers. But it does not include many law graduates with legal jobs in government, publishing, community legal centres, teaching, corporations, or on the bench. Nor does it include the many jobs law graduates have that are not of an essentially legal nature.

A substantial proportion of graduates will never go into private or even government practice. A further proportion only remain in practice for a limited period. While no major longitudinal studies on this issue have been reported in Australia, a number of smaller studies are available. ${ }^{26}$ The Graduate Careers Council of Australia Graduate Destination Surveys for 1991 and 1992 show that 85.9\% (1991) and 85.1\% (1992) of the previous year's graduates who were in fulltime work were "lawyers". ${ }^{27}$

In 1987, the Pearce Report surveyed law graduates of 2 to 6 years standing. $85 \%$ reported that they did work of an "essentially 
legal nature” in their first job. ${ }^{28}$ But only $64 \%$ had a job in private legal practice as their first job, while a further $13 \%$ worked for the government. $^{29}$ After 2-6 years only 56\% were working in the private legal profession while a further $19 \%$ were working as lawyers in government. Some of the rest described themselves as doing work of an essentially legal nature. However only those in private practice and a few of those in government would hold practising certificates and therefore be "lawyers" in the sense that term has been defined here. Table 4 sets out these findings. ${ }^{30}$

Table 4: Pearce Survey: 1979, 1980, 1982 and 1983 Graduates in 1985 (\%)

\begin{tabular}{lcc}
\hline Type of Work & First Job & 1985 Job \\
\hline Work of an Essentially Legal Nature & & 56 \\
Private legal practice & 64 & 19 \\
Government & 13 & 11 \\
Other & 8 & 86 \\
TOTAL & 85 & \\
Work Not of an Essentially Legal Nature & 2 \\
Accountancy & 3 & 1 \\
Other profession & 1 & 3 \\
Government & 5 & 4 \\
Other private industry & 3 & 2 \\
Other & 2 & 14 \\
TOTAL & 14 & $(155)$ \\
Not Applicable & $100 \%$ & \\
\hline TOTAL & $755)$ & \\
\hline
\end{tabular}


TABLE 5: Employment of 1976-1991 Law Graduates as at 30 April the Following Year

\begin{tabular}{|c|c|c|c|c|c|c|c|c|}
\hline & 1976 & 1977 & 1979 & 1980 & 1988 & 1989 & 1990 & 1991 \\
\hline FURTHER STUDIES & 32.8 & 37.4 & 46.5 & 51.4 & 38.6 & 39.2 & 36.7 & 33.8 \\
\hline Professional Practice & 44.3 & 42.2 & 30.8 & 26.1 & 34.3 & 34.6 & 43.7 & \\
\hline Government Service & 7.8 & 8.7 & 8.8 & 10.0 & 11.0 & 10.1 & 9.7 & \\
\hline Other private/non-profit & 2.3 & 2.6 & 4.3 & 3.3 & 4.8 & 4.0 & & \\
\hline Teaching & 1.2 & 1.2 & 1.4 & 1.7 & 0.6 & 1.2 & 0.9 & \\
\hline Other & 0.4 & 0.6 & 0.4 & 1.0 & & & & \\
\hline SEEKING EMPLOYMENT & 5.7 & 4.3 & 2.2 & 3.1 & 2.2 & 1.9 & 1.7 & 2.2 \\
\hline $\begin{array}{l}\text { UNAVAILABLE FULLTIME EMPLOYMENT } \\
\text { OR STUDY (INCLUDES PART TIME }\end{array}$ & 3.9 & 1.7 & 3.2 & 2.0 & 5.0 & 2.2 & 1.2 & 3.0 \\
\hline $\begin{array}{l}\text { EMPLOYED) } \\
\text { OVERSEAS }\end{array}$ & 1.8 & 2.0 & 2.5 & 1.8 & 3.1 & 4.5 & 3.6 & 4.1 \\
\hline
\end{tabular}


This is consistent with Weisbrot's analysis of 1981 Australian Census data which showed that only $72 \%$ of Australians with legal qualifications worked directly in the law. After 20 years of work, the figure dropped to $66 \% .^{31}$ The percentages of "lawyers" holding practising certificates would be even lower. These figures probably show a higher separation rate from work of "an essentially legal nature” than Pearce's because they include law graduates from a longer span of time.

It appears then that only less than $60 \%$ of law graduates are practitioners or "lawyers" as defined by the existence of a practising certificate a few years after graduation. The percentage lessens as time goes on. Up to $20 \%$ are likely to have legal jobs in government. The fact that law graduates frequently take other jobs allows for some flexibility. Numbers of law students do not have to be strictly controlled in line with the current demand for private practitioners.

\section{Employment of Law Graduates}

A conclusion that the recent ratio of students to lawyers has not been too high, is supported by the fact that law graduates have remained highly employable. Table 5 summarises figures from the Graduate Careers Council of Australia which show that law graduates still enjoy some of the highest rates of employment of any discipline. ${ }^{32}$ In 1992, 96.3\% of the previous year's law graduates were employed or in fulltime study six months after graduation, second only to medicine and pharmacy, and far above the national average of $70 \%$ for all graduates. ${ }^{33}$

The Commonwealth Department of Education, Employment and Training has also commented on this situation, More expensive graduates per unit in the sciences and technologies have lower utilisation ratios than law graduates. The twist in the tale is that high employment outcomes are evident in the field of law that public policy has sought to limit whereas employment outcomes are low in fields such as engineering that public policy has sought to increase. DEET's analysis of structural change trends over 1986 to 1991, moreover, indicates that supply should be at least maintained at current levels if not increased through to 2001 in the very fields that some would suggest are tending towards oversupply, viz. health and diagnostic treatment practitioners, 
lawyers, accountants and computer professionals. ${ }^{34}$

\section{DEMAND FOR LAWYERS}

It is difficult to predict what the future demand for lawyers will be. The forecasters of a lawyer glut see the issue as whether the Australian legal profession can continue to sustain this level of growth. But their vision is too narrow. Demand for lawyers is rapidly becoming internationalised, ${ }^{35}$ and it has already been emphasised that law graduates are employed in many areas other than private practice. In this context the issue is really whether all the graduates trained in Australian law schools will find employment in the world wide market. ${ }^{36}$

Even focusing on the demand for law graduates within Australia, there is evidence to suggest that law graduates will continue to find employment. Statistics show that the number of lawyers has been doubling approximately every twelve years for the last thirty or forty years. For example the figure for 1966 doubled in the ten years to 1976. This figure doubled again around 1988, 12 years later (see Table 1 ).

The number of lawyers has also increased relative to population. Table 6 shows the lawyer to population ratios for 1947 to 1992 based on Australian Bureau of Statistics Census data and estimated resident populations. Overall the number of lawyers has increased at a greater rate than the population throughout this century.

TABLE 6: Ratio of Australian Lawyers to Population 19471991

\begin{tabular}{cccc}
\hline Year & Lawyers & Population & $\begin{array}{c}\text { Lawyers per } \\
1000 \text { Population }\end{array}$ \\
\hline 1911 & 2955 & 4500000 & 0.66 \\
1933 & 4345 & 6600000 & 0.66 \\
1947 & 5711 & 7600000 & 0.75 \\
1961 & 6736 & 10500000 & 0.64 \\
1966 & 6242 & 11600000 & 0.54
\end{tabular}




\begin{tabular}{llll}
1971 & 10299 & 12700000 & 0.81 \\
1975 & 12580 & 13900000 & 0.91 \\
1976 & 12909 & 14000000 & 0.92 \\
1981 & 15524 & 14900000 & 1.04 \\
1982 & 16400 & 15200000 & 1.08 \\
1983 & 16100 & 15400000 & 1.05 \\
1984 & 17000 & 15600000 & 1.09 \\
1986 & 17100 & 15800000 & 1.08 \\
1986 & 17500 & 16000000 & 1.09 \\
1987 & 18700 & 16300000 & 1.15 \\
1988 & 22400 & 16500000 & 1.36 \\
1989 & 25000 & 16800000 & 1.49 \\
1990 & 25800 & 17000000 & 1.52 \\
1991 & 27000 & 17300000 & 1.56 \\
\hline & & & \\
\hline
\end{tabular}

Those who warn of a lawyer glut in the near future believe that supply will soon outstrip demand. However, demand for lawyers depends on the needs of the community and in particular how its economy is organised, rather than just the size of its population. ${ }^{37}$ An increase in population is not necessary to support an increase in lawyers, if other changes in the social or economic structure occur. In the past the profession and the number of students studying law have expanded at the same time.

At a broad level, the expansion of lawyer numbers is due to the shift to a service-oriented economy over the last fifty years, and in particular the huge expansion in business activity and investment in Australia since the 1950s. For example Mendelsohn and Lippman have shown how changes to the structure of the economy and corporate activities in the 1960s led to the expansion of legal services, and ultimately the emergence of the corporate law firm to serve the corporate sector. ${ }^{38}$ In addition, growth in the public sector, especially in administrative law, has led to a growth in government lawyering. ${ }^{39}$ The welfare sector has also expanded, 
creating more jobs for lawyers in legal aid and community legal centres. $^{40}$

The problem is whether the market for legal services will continue to expand to make room for an increasing number of new graduates, at least in the near future. It is clear that some growth in the legal profession will continue to be necessary as the population and business activity grows. But it is difficult to measure present demand or predict future demand in any more detail. Some researchers have measured changes in the number of land transfers and court proceedings in order to determine the need for lawyers. ${ }^{41}$ But this assumes a narrow, traditional conception of a lawyer's role, and ignores the ingenuity of lawyers in finding and creating new markets for their services. ${ }^{42}$ Lawyers now do much more than the traditional tasks of conveyancing and court-based litigation and predictions of demand for legal services must take this into account. Future demand will also depend on such unpredictable factors as future economic activity, government spending priorities and the development of law by the courts and legislators. ${ }^{43}$ This is an area where more research is necessary.

But we do know that for the last 30 years a ratio of two students to three lawyers has been neither unusual nor disastrous. The Australian legal profession has been able to expand to include many of these graduates. Many others have found employment outside legal practice and even outside Australia.

\section{THE EFFECT OF THE NEW LAW SCHOOLS}

It has been suggested that since a number of new law schools have been opened in the last few years, these statistics do not accurately reflect the "bulge" in law graduates which is yet to occur. The real glut will be in a few years time when all the present law schools are at steady state and graduating students.

In June 1993 all 25 Australian law schools were contacted and asked for their estimates of numbers of LLB students for the next five years, and, in the case of new law schools, when they expected to reach their steady-state number of students. Twenty-two responded. The other three were all established law schools so it was assumed that they would maintain the same enrolments as 1993 for the next five years, and their 1993 enrolments were taken from the Lawasia Directory of Law Courses compiled in July 
1992. ${ }^{44}$ These figures suggest that the number of LLB students will reach approximately 20000 in 1997, by which time all existing law schools should have reached their steady state number of students. This is a very rough projection since the law student figures are only estimates and do not include any new law schools that open between now and then. At this rate, even if the number of practitioners stays the same, the number of LLB students will still not have equalled the number of lawyers in 1997.

If the number of practitioners continues to grow at the same rate for the next four years (1993-1997) as it has in the last twelve years (1981-1993) ${ }^{45}$ the number of practitioners in 1997 will be 33712 . The ratio of students to lawyers would then be $59 \%$, the same as it is now. Even if the number of practitioners grew at half the rate in the next 4 years as it did in the last twelve years, the number of practitioners in 1997 would be 31 439. This would make the percentage of students to practitioners $64 \%$ which is still not out of keeping with the long term trend.

\section{CONCLUSION}

Looking in detail at the ratio of law students to lawyers reveals the lack of useful research about lawyers and legal education in Australia. Even basic statistics such as the number of lawyers and law students have not been collected in a consistent way until recently, and when statistics are quoted, the way they were measured is rarely discussed. Little research on the career paths of law graduates has been published. While there have been some attempts to measure demand or need for legal services, little analysis of trends in the market for legal services has been attempted.

This lack of knowledge about the Australian legal labour market means that we do not have a context in which to explain and understand the present ratio of students to lawyers. While 59\% (1993) appears high, the data collected in this paper suggests that it does not necessarily amount to a "glut". But further research, especially on the future demand for legal services and graduates with legal training, is necessary to draw firm conclusions on whether we are likely to face an oversupply of law graduates.

* BA LLB, Research Assistant, Law School, Griffith University. Although the 
author takes full responsibility for the research reported here, the idea for starting the research came from Professor Charles Sampford.

(C) 1993. (1993) 4 Legal Educ Rev 255.

1 For example, J Gagliardi, “Queensland faces jobless lawyer glut” Courier Mail February 5 1993, C Jones, "Law dean warns of graduate glut” The Australian September 9 1992; G Thompson, "Jobs will be hard to find in the brave new republic”, Australian Financial Review May 51993.

Id Jones.

3 Supra note 1, Gagliardi.

4 This is not to discount concerns about the current state of legal education in Australia. Most would agree that the education provided by most Australian law schools could be improved. See C Parker, and C Sampford, The Key to Legal Education: Quality not Quantity, (1993) 67 Law Institute 798. See D Weisbrot, Recent Statistical Trends in Australian Legal Education (1990-91) 2 Legal Educ Rev 219 at 242-251 for a discussion of the underfunding of Australian law schools, and D Pearce, E Campbell, D E Harding, \& Commonwealth Tertiary Education Commission, Australian Law Schools: A Discipline Assessment for the CTEC (Canberra: Australian Government Printing Service, 1987) ("the Pearce Report") for a report on the failure of Australian legal education. On the same theme, see, J Crawford, The Future of the Public Law Schools (1991) 9 Professional Leg Educ 1.

5 In Australia no-one has been compiling these statistics in a comprehensive way until recently. For example, many of the professional associations do not even keep records of their membership numbers from one year to the next. Recently the Centre for Legal Education in New South Wales has been established to collect and disseminate such statistics, as well as to engage in research and policy development projects relevant to legal education.

6 See, for example, D Weisbrot, Australian Lawyers (Melbourne: Longman Cheshire, 1990) at 57-58, and also R August, The Mythical Kingdom of Lawyers: America Doesn't Have 70 Percent of the Earth's Lawyers (1992) Sept $A B A 72$, for a discussion of the difficulties in collecting statistics on lawyers.

7 This will not include articled clerks who do not yet have a practising certificate.

8 This seems to be the most consistent series of statistics on lawyer numbers available. For example, the lawyer categories in the Australian census data have been defined differently in different years.

Some people keep up their registration even after they have left practice.

10 The massive expansion in government lawyering has meant that it is now becoming accepted as a standard form of professional practice. However it is unclear what percentage of government lawyers would be members of professional associations since most are not required to have a practising certificate. For example in Queensland, government counsel have only recently been allowed to join the Bar Association as associate members.

11 Members of each of the State and Territory professional associations automatically become members of the Law Council of Australia.

12 The main difficulty with this source is that since the Law Council of Australia is an umbrella organisation, some of the growth in its membership could be due to expansion of the coverage of the association rather than growth in the actual number of people practising.

13 In 1986 the Census classification widened to include all "lawyers" (23 180) but to exclude Judges. Therefore the 1986 figure cannot compare with the figures from other years.

14 It is not clear what this term includes.

15 For example, the Selected Higher Education Statistics series published by the Universities Commission, Commonwealth Tertiary Education Commission and now the Department of Employment, Education and Training. 
For example, Weisbrot has not dealt with this issue with respect to his statistics in Australian Lawyers, supra note 6 at 64, and in Recent Statistical Trends in Legal Education, (1990-1991) 2 Legal Educ Rev 219.

17 The number of students enrolled at Bond University, a private University, have been added for 1992 and 1993. The figure for Bond University was not available for other years.

Pearce Report, supra note 4,448.

Official numbers of students for a particular year are usually not available until the following year.

20 This is confirmed by the fact that the 1965 figure from the Selected Higher Education Statistics series published by the Universities Commission is 3039 which is lower than 4076, the figure in Professor Western's study.

21 A Review of the Barristers and Solicitors Admission Boards Course: Stage One; A Snapshot of the Course in October 1992 (New South Wales: Centre for Legal Education, 1993) Ch 5.

22 See D Weisbrot, Australian Lawyers, supra note 6 at 142. Also, Review of Barristers and Solicitors Admission Boards Course, ibid, found that one third of the enrollees in the course were not actually doing any subject in 1992. This research by the Centre for Legal Education is the first major examination in this area, and no further information is available yet about the progress of enrollees through the course.

See Weisbrot, supra note 6 at 142 for a discussion of the proportion of lawyers qualifying by this means in New South Wales. In $196072 \%$ of new admissions were by Admissions Board courses. By 1978 it was only $29 \%$. Source: Selected Higher Education Statistics, DEET, 1988-1991.

See R Freeman, Legal "Cobwebs": A Recursive Model of the Market for New Lawyers, (1975) 57 The Rev of Economics and Statistics 171, for a discussion of the way this lag between starting law school and entering the job market tends to create a cyclical pattern of shortages and surpluses in the supply of law graduates. It would be worthwhile to examine the surplus of students in the early 1980s and the shortage in the late 1980s from this perspective.

There has been a major longitudinal piece of research on law students from 1965 undertaken by DS Anderson, and JS Western, but they have not published any findings on this particular issue. See for example, DS Anderson, JS Western, and PR Boreham, Law and the Making of Legal Practitioners, in Understanding Lawyers (Sydney: Allen and Unwin 1978).

The term "lawyers" was not defined. Previous years' data on the same issue are not useful as law and legal studies students were reported together. This term was not defined.

These are percentages of the total sample of graduates, not just those in fulltime work unlike the GCCA figures.

Pearce Report: Volume Four, supra note 4 at 74.

31 Weisbrot, supra note 6 at 64.

32 Graduate Careers Council of Australia, Graduate Destination Surveys 1977 to 1991.

33 This may be skewed by the fact that many law graduates do a practical legal training course straight after their degree.

34 Department of Education, Employment and Training, Recent Trends and Current Issues in Higher Education, International Conference on the Transition from Elite to Mass Higher Education, Sydney, 15-18 June 1993, 31. See, for example, L Street, Our Doors Opening Too Slowly (1993) 28 Australian Lawyer 25.

36 This question can also be turned around: Will Australian law schools anticipate and respond to planetary employment skills and knowledge needs for the 
twenty-first century? This is an issue of the quality of Australian legal education.

37 See T W Beed, I G Campbell, and V R Milligan, Planning Tools and the Growth of the Legal Profession in New South Wales, in R Tomasic (ed), Understanding Lawyers (Sydney: Law Foundation of Australia, and George Allen and Unwin, 1978) at 239, and I Ramsay, What do Lawyers do? Reflections on the Market for Lawyers, (1994) 23 International Journal of the Sociology of Law, forthcoming.

38 O Mendelsohn, and M Lippman, The Emergence of the Corporate Law Firm in Australia, (1979) 3 University of New South Wales Law Journal 78-98. See also R Sander, \& H Williams, Why are there so many Lawyers? Perspectives on a Turbulent Market, (1989) Law and Social Inquiry 431, for an explanation of the growth in the number of lawyers in the United States taking into account the shift to a service economy and other factors.

39 See Weisbrot, supra note 6 at 60 for a discussion of the growth of government lawyering. See also J Goldring, \& G Hawker, Lawyers in a Government Department: A Report and Suggestions for Further Research, 1985 XLIV Australian Journal of Public Administration 287.

40 Some attempts have been made to measure demand in this area. See for example M Cass, and J Western, Legal Aid and Legal Need (Australia: Commonwealth Legal Aid Commission, 1980) for a discussion of this, and $\mathrm{M}$ Cass, and R Sackville, Legal Needs of the Poor: Australian Government Commission of Inquiry into Poverty (Canberra: AGPS, 1975).

41 Nieuwenhuysen \& Williams-Wynn, How Labour Markets Work (Melbourne: Longman Cheshire, 1982) and D M Yorke, Some Aspects of the Labour Market for the Legal Profession in Western Australia, (1984) 27 Economic Activity 12.

See S Rosen, The Market for Lawyers, (1992) The Journal of Law and Economics, 215 at 224, for an analysis of the legal labour market in the United States.

43 For example in the last thirty years the expansion of administrative law and family law has lead to an expansion of legal services.

44 The Lawasia Directory of Law Courses in the Asia and West Pacific Regions (Centre for Legal Education: Sydney, 1992). It should be noted that some of the 1993 figures collected for numbers of enrolments in this poll differed from those published in the Lawasia Directory. However most disparities were not significant. The others can be explained by the fact that the Lawasia Directory figures sometimes included legal studies students, postgraduate students and legal practice students.

This twelve year period covers the recession of the early 1980s and the boom of the late 1980s. 